JIPS, Vol. 1 No. 1

Halaman: 22 - 28

Desember 2020
Jurnal Inovasi Pembelajaran di Sekolah

DOI: https://doi.org/10.51874/jips.v1i01.4

ISSN 2774-9363 (Cetak)

ISSN 2774-9746 (Online)

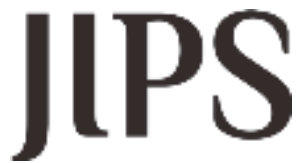

Jurnal Inovasi Pembelajaran di Sekolah

\title{
Pengaruh Model TSTS Berbasis Media Qna Puzzle Terhadap Hasil Belajar Siswa Tema 3 Subtema 2 Kelas III SDN Petompon 02 Semarang
}

\author{
Refine Dezan Aryono Dewi \\ Pendidikan Guru Sekolah Dasar, Fakultas Ilmu Pendidikan \\ Universitas PGRI Semarang
}

Email: Refinedezan@gmail.com

\begin{abstract}
Abstrak
Penelitian ini bertujuan untuk mengetahui pengaruh model Two Stay Two Stray (TSTS) berbasis media QnA Puzzle pada materi Tema 3 Sub tema 2 untuk siswa kelas III Sekolah Dasar. Penelitian quasi eksperimen dengan subjek siswa kelas III A sebagai kelas eksperimen yang diberikan pembelajaran Two Stay Two Stray (TSTS) berbasis media QnA Puzzle dan kelas III B sebagai kelompok kontrol yang diberikan pembelajaran konvensional dengan media QnA Puzzle. Data diperoleh dari melalui tes dan dianalisis menggunakan uji U Mann Whitney. Data hasil belajar diperoleh melalui pretes dan postes dan dianalisis menggunakan uji U Mann Whitney. Hasil penelitian menunjukkan bahwa model Two Stay Two Stray (TSTS) berbasis media QnA Puzzle berpengaruh positif terhadap hasil belajar tematik tema 3 subtema 2 untuk siswa kelas III SDN Petompon 02. Hal ini terbukti dari hasil uji U Mann Whitney dengan nilai signifikansi 0,037, rata-rata hasil belajar pada pembelajaran ini mencapai 84,03 yang secara signifikan lebih baik daripada pembelajaran langsung yang memiliki rata-rata 78,33. Perbedaan ini karena adanya proses pembelajaran yang bermakna, lebih mengaktifkan siswa dalam proses belajar, memiliki tanggungjawab untuk menyampaikan hasil diskusi maupun mencari informasi hasil diskusi dari kelompok lain dan menyampaikan kembali ke kelompoknya. Pembelajaran yang lebih menyenangkan mendorong siswa untuk aktif belajar sehingga berdampak pada perolehan hasil belajar yang lebih baik daripada pembelajaran langsung.
\end{abstract}

Kata Kunci: Two Stay Two Stray, QnA Puzzle, Hasil Belajar, Sekolah Dasar

\begin{abstract}
This research purposed to know the model influence of Two Stay Two Stray (TSTS) based on media Puzzle QnA on material of Tema 3 Sub tema 2 for third grade students of Primary School. The experiment quasi research with subject third grade students as a experiment class which was given learning of Two Stay Two Stray (TSTS) based on media Puzzle QnA and third B grade as a control group was given konventional learning with media Puzzle QnA. The learning result data got through pretest and post test and was analysed used U Mann Whitney test. The result research showed that model of Two Stay Two Stray (TSTS) based on Puzzle QnA has positive influence to tematik learning result of tema 3 subtema 2 to third grade students of SDN Petompon 02. This case proved from the test result of $U$ Mann Whitney with significant score 0,037, with averages the study result on this learning reached 84,03 significantly more better than direct learning has average 78,33. This difference happened because there is the meaningfull learning process, more activated students in study process, has responsible to convey discussion result or looked for discussion result from other group and reconvey to their groups. The happiness learning encouraged students to be active to study so has impact to get the study result more better than direct learning.
\end{abstract}

\section{Keywords: Two Stay Two Stray, QnA Puzzle, Hasil Belajar, Sekolah Dasar}




\section{PENDAHULUAN}

Media yang dikembangkan guru harus sesuai dengan karakteristik dan kebutuhan siswa. Gerlech \& Ely (1971) dalam Arsyad (2014:3) mengatakan bahwa media apabila di pahami secara garis besar adalah manusia , materi , atau kejadian yang membangun kondisi yang membuat siswa mampu memperoleh pengetahuan, ketrampilan , atau sikap. Heinich dan kawan - kawan (1982) mengemukakan istilah medium sebagai perantara yang mengantar informasi antara sumber dan penerima. Apabila media itu membawa pesan - pesan atau informasi yang bertujuan instruksional atau mengandung maksud - maksud pengajaran maka media itu disebut media pembelajaran. Hamidjodjo dalam Latuheru (1993) memberi batasan media sebagai semua bentuk perantara yang digunakan oleh manusia untuk menyampaikan atau menyebar ide, gagasan, atau pendapat sehingga ide, gagasan, atau pengantar yang dikemukakan itu sampai kepada penerima yang di tuju.

Media pembelajaran sangat membantu berjalannya proses belajar mengajar di kelas. Apabila pemanfaatan media pembelajaran sesuai dengan tujuan pembelajaran, maka akan tercipta suatu pembelajaran yang bermakna sehingga dapat meningkatkan minat belajar bahkan hasil belajar siswa. Salah satu bentuk inovasi dalam media pembelajaran yang dapat di gunakan adalah media pembelajaran yang berbasis puzzle untuk merangsang kreatifitas siswa serta memudahkan siswa untuk mengingat . Guru tidak selalu berperan sebagai penyaji materi ( teacher) tetapi karena penyajian materi bisa di ganti oleh media QnA Puzzle, maka peran guru bisa beralih menjadi fasilitator belajar yaitu memberikan kemudahan bagi para siswa untuk belajar.

Proses pembelajaran yang baik merupakan kegiatan yang menjadikan siswanya dapat memahami materi yang disampaikan. Langkah ini akan mudah terwujud apabila menggunakan media. Games menjadi bagian dari media karena sifatnya dapat membantu menyampaikan pesan. Games yang ada termasuk yang mendidik dan dapat mengeksplorasi pikiran. Di antara Games tersebut adalah dengan puzzle. Menurut Yustisia (2013:118) Puzzle merupakan permainan yang dapat merangsang kemampuan visual dan spasial anak. Hampir sepanjang waktu anak akan lebih suka bermain puzzle daripada permainan lain, mereka akan senang dan tampak berkonsentrasi mengotak-atik puzzle yang sedang mereka mainkan, sehingga dapat disimpulkan bahwa puzzle adalah suatu permainan yang dapat meningkatkan daya kreatifitas dan ingatan siswa lebih mendalam untuk mencoba menyelesaikan suatu masalah. Puzzle bagi anak-anak dinilai mampu merangsang kemampuan berpikir sekaligus mengasah kemampuan kecerdasan si anak itu sendiri .

Model pembelajaran Two Stay Two Stray (TSTS) dikembangkan oleh Spencer Kagan (1990) dalam Huda (2014 :207) merupakan sistem pembelajaran kelompok dengan tujuan agar siswa dapat saling bekerjasama, bertanggung jawab, saling membantu memecahkan masalah, dan saling mendorong satu sama lain untuk berprestasi. Model ini juga melatih siswa untuk bersosialisasi dengan baik. Menurut Taniredja (2014:121), langkah model Two Stay Two Stray (TSTS), siswa bekerja sama dalam kelompok yang berjumlah 4, setelah selesai, dua orang dari masing-masing menjadi tamu kedua kelompok yang lain. Dua orang yang tinggal dalam kelompok bertugas membagikan hasil kerja dan informasi ke tamu mereka. Tamu mohon diri dan kembali ke kelompok mereka sendiri dan melaporkan temuan mereka dari kelompok lain. Kelompok mencocokkan dan membahas hasil kerja mereka. Beberapa kelebihan dari model Two Stay Two Stray (TSTS) antara lain: (1) dapat diterapkan pada semua kelas atau tingkatan; (2) kecenderungan belajar siswa menjadi lebih bermakna; (2) lebih berorientasi pada keaktifan dan membantu meningkatkan minat dan prestasi belajar.

Beberapa masalah yang teridentifikasi di SD N Petompon 02 Semarang antara lain banyak siswa yang kurang dalam pemahaman materi pembelajaran; masih memerlukan sebuah media alternatif dalam pembelajaran, agar lebih memudahkan siswa dalam pemahaman pembelajaran dan membuat siswa lebih aktif dalam berdiskusi. Dibutuhkan media QnA Puzzle yang dapat membuat 
siswa lebih paham dan mudah masuk kedalam ingatan siswa namun bersifat santai akan tetapi terus belajar. Penelitian ini dilakukan untuk mengetahui pengaruh model Two Stay Two Stray (TSTS) berbasis media QnA Puzzle pada materi Tema 3 Sub tema 2 untuk siswa kelas III Sekolah Dasar.

\section{METODE PENELITIAN}

Penelitian ini dilaksanakan di Sekolah Dasar Negeri Petompon 02 Semarang, pada siswa kelas III A dan III B, dan dilaksanakan pada bulan Desember tahun pelajaran 2018 / 2019. Penelitian ini berfokus pada tema 3 subtema 2 materi Wujud Benda kelas 3 Sekolah Dasar. Dalam penelitian ini peneliti mengambil 2 kelas yakni yang terdiri dari 1 kelas eksperimen yang akan diterapkan model Two Stay Two Stray berbasis media QnA Puzzle yang terbimbing dan pada kelas kontrol diterapkan model pembelajaran yang konvensional. Desain penelitian yang digunakan adalah Quasi experimental design. Kelas III A sebagai kelas eksperimen yang diterapkan model Two Stay Two Stray berbasis media QnA Puzzle yang terbimbing dan pada kelas kontrol yaitu IIIB diterapkan model pembelajaran yang konvensional. Data hasil belajar diperoleh melalui tes dilakukan sebelum dan sesudah pembelajaran dari masing-masing kelompok.

\section{HASIL DAN PEMBAHASAN}

Penelitian eksperimen ini bertujuan untuk menganalisis pengaruh model Two Stay Two Stray (TSTS) berbasis media QnA Puzzle terhadap hasil belajar tematik tema 3 subtema 2 untuk siswa kelas III SDN Petompon 02. Penelitian diawali dengan memberikan pretes, proses pembelajaran dan postes pada kelompok eksperimen yang menerapkan model Two Stay Two Stray (TSTS) berbasis media QnA Puzzle yang dibandingkan dengan kelompok kontrol yang menerapkan pembelajaran langsung.

Kemampuan awal sebelum dilakukan pembelajaran antara kelompok kontrol dan eksperimen relatif sama. Rata-rata hasil belajar sebelum dilakukan pembelajaran pada kelompok eksperimen sebesar 69,36 sedangkan pada kelompok kontrol sebesar 68,06. Jika dibandingkan dengan skor kriteria minimal (SKM) yang dipakai oleh sekolah sebesar 70, sebagian siswa belum mencapai ketuntasan belajar. Pada kelompok kontrol masih ada $42 \%$ siswa yang belum tuntas, sebanyak 50\% tergolong cukup, selebihnya $8 \%$ siswa memiliki kemampuan awal yang baik. Pada kelompok eksperimen, sebanyak $50 \%$ siswa belum tuntas, $28 \%$ siswa tergolong cukup dan $8 \%$ baik. Hasil uji U Mann Whitney diperoleh nilai signifikansi $0,733>0,05$, yang berarti tidak ada perbedan signifikan hasil belajar sebelum pembelajaran antara kedua kelompok.

Penelitian di laksanakan di SDN Petompon 02 Semarang, pada siswa kelas III A dan Siswa Kelas III B. Penelitian di laksanakaan selama tiga kali pembelajaran ( tiga hari ) di tanggal 23, 24, dan 25 Januari 2019 untuk kelas kontrol dan tanggal 28, 29, 30 januari 2019 untuk kelas eksperimen pada masing-masing kelas. Untuk penelitian di kelas kontrol dimulai pada awal pembelajaran hingga akhir. Untuk siswa kelas III B sebagai kelompok kontrol yakni pembelajaran langsung melalui diskusi seperti biasa, tanya jawab, dan ceramah, semua materi di sajikan oleh guru. Untuk kelas III A sebagai kelompok eksperimen yaitu pembelajaran menggunakan model pembelajaran TSTS berbasis media QnA Puzzle . Proses pembelajaran pertama di kelompok eksperimen diawali dengan berdoa, menanyakan kehadiran siswa, menjelaskan tujuan dari pembelajaran yang akan kita pelajari bersama, menjelaskan proses pembelajaran yang akan dilakukan yaitu melalui berdiskusi Two Stay Two Stray (TSTS), menerangkan tentang cara menggunakan puzzle, kemudian membagi soal pretest kepada siswa. Siswa menjawab soal pretest secara mandiri dan setelah selesai langsung mengumpulkan ke meja guru . kemudian guru membagi siswa berkelompok masing-masing kelompok berisi 4 orang. Guru membagi QnA puzzle pada tiap kelompok dengan mengacak setiap kepingnya di atas meja. setelah semua terbagi, guru memberikan arahan untuk mengangkat papan puzzle terlebih dahulu dan 
mengajak siswa berhitung bersama satu sampai tiga untuk memulai menyusun puzzle. Setelah puzzle tersusun siswa membaca soal yang ada di dalam puzzle untuk kemudian didiskusikan serta di cari jawabannya. Setelah mendapat jawaban dari soal tersebut, perwakilan kelompok maju kedepan dengan membawa puzzle untuk menjawab pertanyaan di dalam puzzle tersebut untuk kemudian di tukar dengan lembar jawaban diskusi dan soal diskusi. Kelompok yang tercepat dalam menyelesaikan soal di dalam puzzle dapat memilih soal yang sudah di bentuk lintingan. Guru berkeliling mengecek jawaban siswa sekaligus menilai dan mengoreksi apabila ada yang salah. Setelah semua selesai, guru menanyakan kepada tiap-tiap kelompok siapa yang akan bertamu dan siapa yang akan tinggal.

Agar semua siswa mengetahui semua soal yang ada di dalam lintingan, maka dilakukan proses bertamu dan tinggal di kelompoknya. Karena masing-masing kelompok terdapat 4 siswa, maka dua orang tinggal di kelompok yang bertugas memberikan penjelasan kepada tamu yang datang dan 2 siswa lainnya bertamu kelompok lain untuk mendapatkan informasi soal-soal yang diperoleh dari kelompok lain. Guru memberikan kode dengan suara agar jalannya bertamu bersamaan. Misalnya guru mengucapkan bertamu 1, maka 2 orang dari kelompok 1 bertamu ke kelompok 2, dua orang dari kelompok 2 bertamu ke kelompok 3 dan seterusnya dua orang dari kelompok 9 bertamu ke kelompok 1. Proses bertamu dilanjutkan terus dengan kode dari guru dengan kata-kata bertamu 2, bertamu 3 dan seterusnya sampai bertamu 9. Akhirnya masing-masing kelompok kembali lagi ke kelompoknya. Masing-masing yang bertamu bertugas mencatat info sebagai bekal untuk memberikan penjelasan pada kelompoknya. Setelah siswa kembali ke kelompoknya masing-masing guru memberi arahan siswa untuk berdiskusi ( sharring informasi ke kelompoknya, dan yang bertugas tinggal agar dapat mencatat dan memahami informasi tersebut ).

Setelah selesai semua, guru memberikan intruksi kepada siswa untuk memasukan semua buku, dan perlengkapan di dalam tas yang tertinggal di atas meja hanya bulpoin atau pensil. Setelah semua terkondisikan dengan baik, kemudian guru membagi soal mandiri kepada siswa, tiap siswa mendapatkan soal sendiri -sendiri. Siswa mengerjakan soal secara mandiri, setelah selesai, siswa mengumpulkan soal tersebut ke meja guru. Kemudian guru melakukaan tanya jawab kepada siswa tentang materi yang sudah di pelajari, menanyakan ada yang ingin ditanyakan atau tidak, menanyakan ada kesulitan atau tidak, dan menjelaskan ketika ada yang bertanya. Sebelum pembelajaran berakhir guru mengajak siswa bernyanyi bersama untuk menumbuhkan semangat siswa, kemudian pembelajaran di akhiri dengan berdoa bersama. Kegiatan ini dilakukan hampir sama untuk pertemuanpertemuan selanjutnya. Pembelajaran ketiga dilaksanakan sedikit berbeda karena mereview pembelajaran sebelumnya dan menjelaskan pembelajaran yang akan di pelajari hari ini, melakukan tanya jawab terhadap siswa untuk mengetauhi tingkat pemahaman siswa, serta dapat menjelaskan kembali ketika siswa ada yang belum paham. kegiatan pembelajaran awal masih sama dengan pembelajaran sebelumnya, membagi siswa berkelompok, kemudian masing-masing perwakilan kelompok maju kedepan kelas untuk mengambil soal dan lembar jawaban, Setelah kegiatan belajar mengajar selesai, kemudan berikutnya adalah postes untuk mengetahui hasil belajar. Sebelum membagi soal post test, guru mengajak siswa bernyanyi untuk menghilangkan kepenatan siswa dan kembali meningkatkan rasa semangat siswa. Selanjutnya guru membagi lembar post test kepada siswa untuk di kerjakan secara mandiri, setelah guru menanyakan kesiapan siswa dan hal-hal yang masih belum dipahami. Setelah selesai siswa mengumpulkan hasil jawaban di meja guru. guru menanyakan apakah ada yang mau di tanyakan sebelum mengakhiri pembelajaran hari ini. Setelah tidak ada yang bertanya guru mengakhiri pembelajaran dengan berdoa bersama yang dipimpin oleh siswa yang bertugas untuk memimpin berdoa pada waktu itu.

Setelah Postest diperoleh rata-rata hasil belajar pada kelompok eksperimen sebesar 84,03 sedangkan pada kelompok kontrol sebesar 78,33. Jika dibandingkan dengan skor kriteria minimal (SKM) yang dipakai oleh sekolah sebesar 70, menunjukkan bahwa hasil belajar siswa telah mencapai 
ketuntasan belajar. Pada kelompok kontrol masih ada 19\% siswa yang belum tuntas, sebanyak 50\% tergolong cukup, selebihnya $14 \%$ siswa tergolong baik dan $17 \%$ sangat baik. Pada kelompok eksperimen, sebanyak $11 \%$ siswa belum tuntas, $28 \%$ siswa tergolong cukup, $28 \%$ baik dan $33 \%$ sangat baik.

Hasil uji U Mann Whitney diperoleh nilai signifikansi 0,037 < 0,05, yang berarti ada perbedan signifikan hasil belajar setelah pembelajaran antara kedua kelompok. Dilihat dari mean rank pada kelompok eksperimen sebesar 41,60 dan pada kelompok kontrol 31,40, yang berarti bahwa pembelajaran TSTS berbantuan media QnA Puzzle lebih baik daripada pembelajaran langsung.

Hasil belajar setelah dilakukan pembelajaran antara kelompok kontrol dan eksperimen dilihat dari postes, dengan hasil seperti tercantum pada Tabel :

Tabel 1. Data Postest

\begin{tabular}{llcccc}
\hline \multirow{2}{*}{ Interval } & \multirow{2}{*}{ Kriteria } & \multicolumn{2}{c}{ Kontrol } & \multicolumn{2}{c}{ Eksperimen } \\
& & F & $\%$ & F & $\%$ \\
\hline$<70$ & Belum tuntas & 7 & 19 & 4 & 11 \\
$70-80$ & Cukup & 18 & 50 & 10 & 28 \\
$81-90$ & Baik & 5 & 14 & 10 & 28 \\
$91-100$ & Sangat baik & 6 & 17 & 12 & 33 \\
Jumlah & & 36 & 100 & 36 & 100 \\
\hline
\end{tabular}

Tabel diatas memperlihatkan bahwa pada kelompok kontrol masih ada 19\% siswa yang belum tuntas, sebanyak 50\% tergolong cukup, selebihnya $14 \%$ siswa tergolong baik dan $17 \%$ sangat baik. Pada kelompok eksperimen, sebanyak $11 \%$ siswa belum tuntas, $28 \%$ siswa tergolong cukup, $28 \%$ baik dan $33 \%$ sangat baik.

Pendidikan memiliki pengaruh yang besar terhadap kehidupan peserta didik di masa kini maupun di masa kelak saat peserta didik sudah dewasa. Keberhasilan peserta didik dalam pendidikan tidak terlepas dari cara seorang guru mendidik peserta didik. Salah satu indikator pendidikan bermutu adalah perolehan hasil belajar siswa yang baik. Tolak ukur keberhasilan pembelajaran pada umumnya adalah prestasi belajar. Prestasi belajar atau hasil belajar siswa dalam belajar merupakan salah satu keberhasilan pembelajaran. Nilai hasil belajar siswa dapat ditingkatkan melalui proses pembelajaran yang efektif dan efesien dengan ditunjang sarana dan prasarana yang memadai. Untuk mewujudkan pembelajaran yang bermakna pada siswa, dalam kurikulum 2013 diperlukan suatu perencanaan pembelajaraan yang matang. Guru juga harus kreatif dan inovatif dalam menggunakan dan mengembangkan media pembelajaran guna menunjang proses belajar mengajar sehingga tercipta suatu pembelajaran yang efektif dan efesien.

Media pembalajaran sangat membantu berjalannya proses belajar mengajar di kelas. Apabila pemanfaatan media pembelajaran sesuai dengan tujuan pembelajaran, maka akan tercipta suatu pembelajaran yang bermakna sehingga dapat meningkatkan minat belajar bahkan hasil belajar siswa. Salah satu bentuk inovasi dalam media pembelajaran yang dapat di gunakan adalah media pembelajaran yang berbasis QnA puzzle yakni media Puzzle dengan inovasi baru untuk merangsang kreatifitas siswa serta memudahkan siswa untuk mengingat. Dalam hal ini, guru tidak selalu berperan sebagai penyaji materi (teacher) tetapi karena penyajian materi bisa di ganti oleh media QnA Puzzle, maka peran guru bisa beralih menjadi fasilitator belajar yaitu memberikan kemudahan bagi para siswa untuk belajar. QnA Puzzle melibatkan partisipasi peserta didik aktif sejak kegiatan pembelajaran dimulai. Peserta didik diajak untuk turut serta dalam semua proses pembelajaran, tidak hanya mental akan tetapi juga melibatkan fisik. Dengan ini peserta didik akan merasakan suasana yang lebih 
menyenangkan sehingga hasil belajar dapat dimaksimalkan. . Fungsi kegunaan dari QnA (Question and Answer ) Puzzle itu sendiri adalah membangun saraf-saraf otak yang memberi efek menyegarkan ingatan sehingga fungsi kerja otak kembali optimal karena otak dibiasakan untuk terus menerus belajar dengan santai. Karena belajar dengan santai inilah yang dapat membuat siswa menjadi lebih paham dan mudah masuk dalam ingatan siswa sehingga siswa tidak mudah lupa dengan materi yang sudah diajarkan. Hal ini terlihat dari hasil penilaian proses diskusi dan tes mandiri yang menunjukkan perubahan yang semakin membaik.

Proses pembelajaran yang dilakukan ini memiliki beberapa kelebihan karena guru tidak lagi harus menjelaskan satu demi satu, siswa cenderung aktif memecahkan permasalahan secara kelompok dan menyampaikan kepada kelompok lain, serta mencari informasi hasil diskusi kelompok lain. Hal ini sesuai dengan pendapat Huda (2014: 207) yang menyatakan bahwa model Two Stay Two Stray memiliki beberapa kelebihan antara lain: 1) Dapat diterapkan pada semua kelas atau tingkatan; 2) Kecenderungan belajar siswa menjadi lebih bermakna; 3) Lebih berorientasi pada keaktifan dan 4) membantu meningkatkan minat dan prestasi belajar. Meskipun waktu yang digunakan relatif lama, karena proses pembelajaran bermakna bagi siswa akan mempengaruhi hasil belajar yang lebih baik.

Model Two Stay Two Stray berbasis media QnA Puzzle membuat siswa merasa senang. Persaan senang inilah yang dapat menjadikan siswa lebih konsenterasi dan aktif dalam pembelajaran, selain itu pembelajarannya juga bersifat santai, serius, namun menyenangkan yang dapat membuat siswa menjadi lebih paham dan materi mudah masuk dalam ingatan siswa, sehingga siswa tidak mudah lupa dengan materi yang sudah diajarkan guru. Jadi siswa tidak merasa bosan atau jenuh dalam pembelajaran. Dengan menumbuhkan semangat serta rasa senang siswa untuk belajar maka dapat meningkatkan proses belajar siswa, sehingga hasil belajar mengalami peningkatan. Dengan model Two Stay Two Stray berbasis media QnA Puzzle siswa juga diajarkan untuk menjadi lebih mandiri, dapat saling bekerjasama, bertanggung jawab, saling membantu memecahkan masalah, saling mendorong satu sama lain untuk berprestasi dan siswa juga diajarkan untuk bersosialisasi dengan baik.

\section{PENUTUP}

Berdasarkan hasil penelitian dan pembahasan dapat diambil simpulan bahwa Model Two Stay Two Stray (TSTS) berbasis media QnA Puzzle berpengaruh positif terhadap hasil belajar tematik tema 3 subtema 2 untuk siswa kelas III SDN Petompon 02. Hal ini terbukti dari hasil uji U Mann Whitney dengan nilai signifikansi 0,037 , rata-rata hasil belajar pada pembelajaran ini mencapai 84,03 yang secara signifikan lebih baik daripada pembelajaran langsung yang memiliki rata-rata 78,33 . Perbedaan ini karena adanya proses pembelajaran yang bermakna, lebih mengaktifkan siswa dalam proses belajar, memiliki tanggungjawab untuk menyampaikan hasil diskusi maupun mencari informasi hasil diskusi dari kelompok lain dan menyampaikan kembali ke kelompoknya. Pembelajaran yang lebih menyenangkan mendorong siswa untuk aktif belajar sehingga berdampak pada perolehan hasil belajar yang lebih baik daripada pembelajaran langsung. Berdasarkan hasil penelitian dapat disarankan sebagai berikut. (1) Model pembelajaran Two Stay Two Stray berbantuan media QnA Puzzle dapat digunakan sebagai alternatif pembelajaran yang mengaktifkan siswa dan meningkatkan hasil belajar. (2) Guru ketika akan menerapkan pembelajaran Two Stay Two Stray berbantuan media QnA Puzzle dapat menyiapkan QnA Puzzle dengan cara mengganti puzzle-puzzle yang ada di pasaran dengan stiker. Gambar-gambar yang sesuai dengan materi dapat dicetak pada stiker yang dapat ditempel pada puzzle yang ada. (3) Ketika akan melaksanakan kegiatan pembelajaran TSTS berbantuan media QnA Puzzle, maka disarankan kepada guru untuk memastikan bahwa hasil penyelesaian pada saat diskusi 
kelompok sudah benar sehingga ketika siswa yang bertugas menjadi penerima tamu akan memberikan penjelasan secara benar.

\section{DAFTAR PUSTAKA}

Arsyad, Azhar. 2014. Media Pembelajaran. Jakarta: Rajawali.

Huda, miftahul. 2014. Model-model pengajaran dan pembelajaran.Yogyakarta: Pustaka pelajar

Taniredja, Tukiran. 2014.model - model pembelajaran inovatif dan efektif. Bandung : Alfabeta

Yustisia, N. 2013. 75 Rahasia Anak Cerdas. Yogyakarta : Ar - ruzz Media 